\title{
Thiemann disease, familial form
}

INSERM

\section{Source}

INSERM. (1999). Orphanet: an online rare disease and orphan drug data base. Thiemann disease, familial form. ORPHA:3314

Thiemann disease is a very rare genetic necrotic bone disorder characterized clinically by painless swelling of the proximal interphalangeal joints associated with osteonecrosis of epiphyses followed by osteoarthritic changes, with onset before 25 years of age and often a benign course. 